SHORT COMMUNICATION

\title{
Effect of Melatonin Supplementation on Physiological Observations in Buffalo Calves under Summer Stress
}

\author{
Vijay D. Domple ${ }^{1}$, Amol R. Padol ${ }^{2}$, C.D. Malapure ${ }^{3}$, Bhupesh P. Kamdi ${ }^{4}$ and Roshan M. Sarode ${ }^{3}$ \\ ${ }^{1}$ Division of Physiology and Climatology, ICAR-IVRI, Izatnagar, Bareilly, INDIA \\ ${ }^{2}$ Division of Pharmacology and Toxicology, ICAR-IVRI, Izatnagar, Bareilly, INDIA \\ ${ }^{3}$ Division of Animal Nutrition, ICAR-IVRI, Izatnagar, Bareilly, INDIA \\ ${ }^{4}$ Division of Pathology, ICAR-IVRI, Izatnagar, Bareilly, INDIA \\ *Corresponding author: VD Domple; E-mail: vijaydomple@gmail.com
}

Received: 07 July, 2020

Revised: 15 Nov., 2020

Accepted: 13 Dec., 2020

\begin{abstract}
A study was undertaken to investigate the effect of melatonin supplementation on physiological parameters in buffalo calves under summer stress. Twelve healthy Murrah buffalo male calves of 6 month to 1 year age group were taken for the study. Buffalo calves were divided into control (CG) and treatment (TG) group. In TG, Melatonin (18 mg/50 kg BW) was injected subcutaneously, two times at $1^{\text {st }}$ and $20^{\text {th }}$ day. Rectal temperature $(\mathrm{RT})\left({ }^{\circ} \mathrm{F}\right)$, respiratory rate (RR) (breathes per minute) and pulse rate (PR) (beats per minute) was recorded by a clinical thermometer, flank movement and by palpating the coccygeal artery respectively. RT, RR and PR differed significantly $(\mathrm{P}<0.05)$ in $\mathrm{CG}$ and TG between morning and afternoon. RT, RR \& $\mathrm{PR}$ were increased significantly $(\mathrm{P}<0.05)$ from morning to afternoon in both the groups. During afternoon the rectal temperature was significantly $(\mathrm{P}<0.05)$ lower in treatment group. In conclusion, melatonin affected the fluctuation in physiological activity.
\end{abstract}

\section{HIGHLIGHTS}

(0 RT, RR and PR differed significantly $(\mathrm{P}<0.05)$ in control and melatonin injected groups between morning and afternoon. ( Injection of melatonin significantly $(\mathrm{P}<0.05)$ lowered rectal temperature in buffalo calves.

Keywords: Melatonin, Physiological observations, Buffalo calves, Summer stress

The world's second most important milch animal is known as Buffalo (Bubalus bubalis). The importance of buffalo to the dairy industry, food security and rural livelihood by providing milk, meat and draught power in tropical and subtropical countries hardly needs emphasizing as the species is an important livestock resource in Asian continent with over $95 \%$ of world's buffalo population (Kumar et al., 2015). Buffaloes have poor heat tolerance than cattle due to many physiological and genetic reasons (less sweat glands and black colored skin) and so are more pronounced to thermal stress. Under excesses thermal loads of heat and work, buffaloes employ moderate levels of sweating and resort to open mouth panting (Das et al., 1999) and have vast agricultural importance by virtue of their high production potential through milk and meat
(Gupta and Das, 1994). Heat stress is a major constraint on animal productivity in tropical conditions. The variation in climatic variables like temperature, humidity and radiations are recognized as the potential hazards in the growth and production of all domestic livestock species. During heat stress, heat increment exceeds heat loss modifying the homeostatic functions. Heat stress elicits an integrative physiological and endocrine modulation altering overall metabolism and helping the animal to sustain during the stressful period. Various in-depth

How to cite this article: Domple, V.D., Padol, A.R., Malapure, C.D., Kamdi, B.P. and Sarode, R.M. (2020). Effect of melatonin supplementation on physiological observations in buffalo calves under summer stress. $J$. Anim. Res., 10(6): 1095-1098.

Source of Support: None; Conflict of Interest: None 
studies on heat and nutritional stress on animals, severely compromising thermoregulatory functions which intern affect the productive potential of animals (Maurya et al., 2004; Wankar et al., 2014). Melatonin (N-acetyl-5methoxytryptamine), an indolamine synthesized from tryptophan in the pineal gland, has been shown to be associated with the regulation of seasonal reproduction in photoperiodic species. Melatonin plays several important physiological functions in mammals, such as reproductive activities regulation, immune enhancement and regulation of dark-light signal transduction. It is also shown to be much potent antioxidant as compared to vitamin $\mathrm{C}$ and $\mathrm{E}$ and plays prominent role in relieving heat stress by influencing cardiovascular system and evaporative heat loss (Harlow, 1987).

The experiment was conducted in summer season of 2015-16 at the Division of Physiology and Climatology, ICAR-Indian Veterinary Research Institute, Izatnagar, Bareilly (India). Twelve healthy Murrah buffalo bull calves between 6 to 12 months of age group belonging to tropical region were selected for the study purpose. The experiment trial was conducted up to 6 week (42 days) period. Animals were divided into two groups viz., control (CG) and treatment (TG) group $(n=6)$. TG received melatonin@18 mg/50 kg body weight, subcutaneously (s/c), on $1^{\text {st }}$ and $20^{\text {th }}$ day of experiment (Kumar et al., 2015).

All the physiological readings were made daily at 08 : 00 am and 02:30 pm. The RT was recorded by a clinical thermometer inserted about $4-5 \mathrm{~cm}$ deep into the rectum of animals so that it remained in contact with the mucous membrane for at least 1-2 minute. The observations were recorded in degree Fahrenheit $\left({ }^{\circ} \mathrm{F}\right)$. The RR was recorded by observing the flank movement for one minute in which each inward and outward movement of the flank was counted as one complete respiration. The respiration rate was expressed as breathes per minute. The PR was recorded by placing the fingertips in the groove on the underside of tail near the rectum by palpating the coccygeal artery for one minute. The PR was expressed as beats per minute. $\mathrm{RT}, \mathrm{RR}$ and PR recorded in the shed.

Data obtained was analyzed statistically by one way ANOVA followed by Tukey's b test (SPSS, Inc., 1997) within group between the days and independent $t$ test for between groups with the help of SPSS 17.0 software.
The physiological responses viz. RT, RR and PR in experimental and control groups have been shown in Table 1. The results indicated that the physiological responses (RT, RR \& PR) were increased significantly $(\mathrm{P}<0.05)$ from morning to afternoon in both the groups. During afternoon the rectal temperature was significantly $(\mathrm{P}<0.05)$ lower in treatment group.

Body temperature is good indicator of heat tolerance in animals. It represents the resultant of all heat loss and heat gain processes of the body. The temperature of the rectal is considered as a good index of body temperature even though there is a variation in different parts of the body core at different times of the day (Srikandakumar et al., 2003). In present study in control and melatonin treated group the RT was significantly $(\mathrm{P}<0.05)$ higher in the afternoon in both the group of animals as compared to morning at every week of study.

In the afternoon, in treatment group of animals within the group a significant $(\mathrm{P}<0.05)$ difference was observed only at $0^{\text {th }}$ and $7^{\text {th }}$ day of study. In accordance to our finding Sharma et al. (2013) also reported that RT increased significantly $(\mathrm{P}<0.05)$ in control and melatonin treated group (Capra hircus) with increasing exposure temperature. Melatonin-treated group had a significantly higher cloacal temperature value than that of the control in layer hens during the hot-dry season (Sinkalu et al., 2014). The high rectal temperature observed for the heat stressed animals was the indicator of disturbance in the homoeothermic status of the animals which was not being effectively countered by the enhanced heat loss by physical and physiological processes of thermolysis (Joshi and Tripathi, 1991). RR is the most consistent of all the physiological responses studied and is affected more by solar radiation than by other influences. RR has been used to evaluate the comfort level of heat stressed cattle (Gaughan et al., 2000). In present study, a significant $(\mathrm{P}<0.05)$ difference in morning and after values were observed control animals as well as treated group of animals throughout the experiment. The control group of animals within the group $0^{\text {th }}$ day values were significantly $(\mathrm{P}<0.05)$ lower than the values of the morning values of $14^{\text {th }}, 28^{\text {th }}$ and $35^{\text {th }}$ day of study. Respiration rate were increased with the increased of heat stress in case of goat and sheep (Maurya et al., 2007; Alam et al., 2011). As per acclimatization mechanism, the bovine increased their $\mathrm{RR}$ in order to loss their excess body heat because non 
Table 1: Physiological parameters of control and melatonin supplemented animals during summer

\begin{tabular}{|c|c|c|c|c|c|c|c|}
\hline Attributes & O day & 7 day & 14 day & 21 day & 28 day & 35 day & 42 day \\
\hline \multicolumn{8}{|c|}{ Rectal Temperature $\left({ }^{\circ} \mathrm{F}\right)$ (Morning) } \\
\hline Control & $100.2 \pm 0.07^{\mathrm{aBC}}$ & $100.2 \pm 0.10^{\mathrm{aC}}$ & $100.2 \pm 0.11^{\mathrm{aB}}$ & $99.2 \pm 0.14^{\mathrm{aB}}$ & $100.02 \pm 0.11^{\mathrm{aB}}$ & $99.17 \pm 0.09^{\mathrm{aB}}$ & $99.9 \pm 0.06^{\mathrm{aB}}$ \\
\hline Treatment & $99.7 \pm 0.41^{\mathrm{aC}}$ & $100.03 \pm 0.21^{\mathrm{aC}}$ & $99.9 \pm 0.17^{\mathrm{aC}}$ & $99.3 \pm 0.05^{\mathrm{aB}}$ & $100.05 \pm 0.04^{\mathrm{aB}}$ & $99.53 \pm 0.26^{\mathrm{aB}}$ & $99.7 \pm 0.14^{\mathrm{aB}}$ \\
\hline \multicolumn{8}{|c|}{ Rectal Temperature ( $\left.{ }^{\circ} \mathbf{F}\right)$ (Afternoon) } \\
\hline Control & $101.6 \pm 0.25^{\mathrm{cB}}$ & $102.3 \pm 0.10^{\mathrm{bA}}$ & $103.2 \pm 0.30^{\mathrm{aA}}$ & $102.6 \pm 0.35^{\mathrm{bA}}$ & $103.05 \pm 0.14^{\mathrm{aA}}$ & $102.4 \pm 0.29^{\mathrm{bA}}$ & $101.7 \pm 0.07^{\mathrm{cA}}$ \\
\hline Treatment & $102.3 \pm 0.09^{\mathrm{aA}}$ & $101.7 \pm 0.22^{\mathrm{bB}}$ & $102.8 \pm 0.12^{\mathrm{aA}}$ & $101.8 \pm 0.10^{\mathrm{bA}}$ & $102.1 \pm 0.37^{\mathrm{aA}}$ & $101.4 \pm 0.29^{\mathrm{bA}}$ & $100.8 \pm 0.30^{\mathrm{bcA}}$ \\
\hline \multicolumn{8}{|c|}{ Respiration rate (breath/min) (Morning) } \\
\hline$\overline{\text { Control }}$ & $30.33 \pm 2.3^{\mathrm{bB}}$ & $33.14 \pm 0.79^{\mathrm{abB}}$ & $36.90 \pm 0.67^{\mathrm{abB}}$ & $35.7 \pm 0.32^{\mathrm{abB}}$ & $36.6 \pm 0.85^{\mathrm{abB}}$ & $37.42 \pm 1.00^{\mathrm{aB}}$ & $35.57 \pm 1.04^{\mathrm{abB}}$ \\
\hline Treatment & $32.16 \pm 1.68^{\mathrm{aB}}$ & $31.4 \pm 0.68^{\mathrm{aB}}$ & $35.66 \pm 0.68^{\mathrm{aB}}$ & $34.7 \pm 0.38^{\mathrm{aB}}$ & $37.09 \pm 0.34^{\mathrm{aB}}$ & $37.28 \pm 0.23^{\mathrm{aB}}$ & $33.14 \pm 0.75^{\mathrm{aB}}$ \\
\hline \multicolumn{8}{|c|}{ Respiration rate (breath/min) (Afternoon) } \\
\hline$\overline{\text { Control }}$ & $43.5 \pm 1.66^{\mathrm{bA}}$ & $42.7 \pm 0.62^{\mathrm{bA}}$ & $66.33 \pm 1.88^{\mathrm{aA}}$ & $52.5 \pm 0.23^{\mathrm{abA}}$ & $61.28 \pm 1.24^{\mathrm{aA}}$ & $59.38 \pm 0.63^{\mathrm{aA}}$ & $47.14 \pm 1.12^{\mathrm{abA}}$ \\
\hline Treatment & $37.8 \pm 1.04^{\mathrm{dAB}}$ & $44.2 \pm 1.92^{\mathrm{dcA}}$ & $64.09 \pm 4.26^{\mathrm{aA}}$ & $52.6 \pm 2.8^{\mathrm{bcA}}$ & $58.19 \pm 3.39^{\mathrm{abA}}$ & $57.09 \pm 4.20^{\mathrm{abA}}$ & $48.76 \pm 1.16^{\mathrm{cA}}$ \\
\hline \multicolumn{8}{|c|}{ Pulse rate (beats/min) (Morning) } \\
\hline Control & $38.00 \pm 0.89^{\mathrm{bB}}$ & $44.66 \pm 0.44^{\mathrm{abB}}$ & $46.09 \pm 0.56^{\mathrm{abB}}$ & $46.19 \pm 0.67^{\mathrm{abB}}$ & $43.19 \pm 0.61^{\mathrm{abB}}$ & $49.57 \pm 0.40^{\mathrm{aB}}$ & $49.00 \pm 0.67^{\mathrm{aB}}$ \\
\hline Treatment & $41.00 \pm 1.61^{\mathrm{bB}}$ & $45.80 \pm 1.12^{\mathrm{abB}}$ & $47.09 \pm 0.70^{\mathrm{abB}}$ & $47.52 \pm 1.33^{\mathrm{abB}}$ & $46.00 \pm 1.00^{\mathrm{abB}}$ & $48.47 \pm 1.14^{\mathrm{abB}}$ & $50.14 \pm 1.48^{\mathrm{aB}}$ \\
\hline \multicolumn{8}{|c|}{ Pulse rate (beats/min) (Afternoon) } \\
\hline Control & $58.83 \pm 2.48^{\mathrm{bA}}$ & $61.5 \pm 1.98^{\mathrm{abA}}$ & $68.30 \pm 1.89^{\mathrm{aA}}$ & $65.00 \pm 1.57^{\mathrm{abA}}$ & $66.66 \pm 0.44^{\mathrm{aA}}$ & $70.07 \pm 1.73^{\mathrm{aA}}$ & $64.38 \pm 1.39^{\mathrm{abA}}$ \\
\hline Treatment & $56.33 \pm 3.77^{\mathrm{bA}}$ & $57.14 \pm 0.55^{\mathrm{bA}}$ & $63.14 \pm 1.37^{\mathrm{abA}}$ & $62.80 \pm 2.23^{\mathrm{abA}}$ & $66.71 \pm 0.34^{\mathrm{aA}}$ & $67.90 \pm 1.06^{\mathrm{aA}}$ & $60.52 \pm 0.37^{\mathrm{abA}}$ \\
\hline
\end{tabular}

Bars bearing different superscript $a, b, c, d$ differ significantly $(\mathrm{P}<0.05)$ in the same group between days and superscript ' $A$ ' ' $B$ ' and ' $C$ ' denotes significant $(\mathrm{P}<0.05)$ difference between the groups during study period.

evaporative heat loss are not sufficient for required heat exchange. Banerjee and Ashutosh (2011) and Vaidya et al. (2011) reported the similar finding in crossbred cattle. RR increased during thermal stress in buffaloes (Wankar et al., 2014). Thermal exposure lead to activation of evaporative heat loss mechanisms involving an increase in respiratory rate which was very much proportional to intensity of thermal exposure (Beatty et al., 2006). Increased respiration is an attempt to increase heat loss by evaporative cooling. In our study a significant $(\mathrm{P}<0.05)$ difference in morning and after values between group were observed in control animals as well as treated group of animals throughout the experiment. With increased heat stress, pulse rate were increased in case of goat (Alam et al., 2011). Regan and Richardson (1938) observed a decrease in pulse rate whereas, Gaalas (1945) and Blaxter and Prince (1945) observed an increase in pulse rate with increase in environmental temperature. In control group as well as treatment group pulse rate increased significantly $(\mathrm{P}<0.05)$ as the exposure temperature increased (Maurya $e t$ al., 2007; Sharma et al., 2013). PR decreased significantly $(\mathrm{P}<0.001)$ during heat exposition (Wankar et al., 2014).
Increase in pulse rate is attributed to two causes. One is the increase in muscular activity controlling the rate of respiration, concurrent with elevated respiration rate. The second is the reduction in resistance of peripheral vascular beds and arteriovenous anastomoses. Increase in pulsation rate increases blood flow from the core to the surface as a result of it more heat is lost by sensible (loss by conduction, convention and radiation) and insensible (loss by diffusion water from the skin) means (Marai et al., 2007).

\section{CONCLUSION}

It may be concluded from present study that administration of Melatonin shown to have an ameliorative effect on over all physiological levels in the growing buffalo calves and the melatonin affected the fluctuation in physiological activity in animals.

\section{ACKNOWLEDGEMENTS}

Authors are highly thankful to Director, I.V.R.I. for providing facilities to conduct the research work. Financial 
support from NICRA and UGC-RGNF fellowship are duly acknowledged.

\section{REFERENCES}

Alam, M.M., Hashem, M.A., Rahman, M.M., Hossain, M.M., Haque, M.R., Sobhan, Z. and Islam, M.S. 2011. Effect of heat stress on behavior, physiological and blood parameters of goat. Progress. Agric., 22: 37-45.

Banerjee, D. and Ashutosh. 2011. Effect of thermal exposure on diurnal rhythms of physiological parameters and feed water intake in Tharparkar and Karan Fries heifers. Biol. Rhythm. Res., 42: 39-51.

Beatty, D.T., Barnes, A., Taylor, E., Pethick, D., McCarthy, M. and Maloney, S.K. 2006. Physiological responses of Bos taurus and Bos indicus cattle to prolonged, continuous heat and humidity. J. Anim. Sci., 84: 972-985.

Blaxter, K.L. and Prince, H. 1945. Variation in some physiological activities of dairy cows. Vet. J., 101: 39-45.

Das, S.K., Upadhyay, R.C. and Madan, M.L. 1999. Heat stress in Murrah buffalo calves. Livest. Prod. Sci, 61: 71-78.

Gaalas, R.F. 1945. Effect of atmospheric temperature on body temperature and respiration rate of Jersy cattle. J. Dairy Sci., 28: $555-563$.

Gaughan, J.B., Holt, S.M., Hahn, G.L., Mader, T.L. and Eigenberg, R. 2000. Respiration rate-is it a good measure of heat stress in cattle? Asian-Aus. J. Anim. Sci., 13: 329-332.

Gupta, S.K. and Das, G.K. 1994. Post partum anoestrus in buffaloes Factors responsible. J. Rem. Vet. Corps, 33: 141151.

Harlow, H.J. 1987. Influence of the pineal gland and melatonin on blood flow and evaporative water loss during heat stress in rats. J. Pineal Res., 4: 147-159.

Joshi, B.C. and Tripathy, K.C. 1991. Heat stress effect on weight gain and related physiological responses of buffalo calves. $J$. Vet. Physiol. Allied Sci., 10: 43-48.

Kumar, A., Mehrotra, S., Singh, G., Narayanan, K., Das, G.K., Soni, Y.K., Mahak Singh., Mahla, A.S., Srivastava, N. and Verma, M.R. 2015. Sustained delivery of exogenous melatonin influences biomarkers of oxidative stress and total antioxidant capacity in summer-stressed anestrous water buffalo (Bubalus bubalis). Theriogenology, 83: 1402-1407.
Marai, I.F.M., Darawany, E.L., Fadiel, A.A. and Hafez, M.A.M. 2007. Physiological traits as affected by heat stress in sheep a review. Small Rum. Res., 71: 1-12.

Maurya, V.P., Naqvi, S.M.K., Joshi, A. and Mittal, J.P. 2007. Effect of high temperature stress on physiological responses of Malpura sheep. Indian J. Anim. Sci., 77: 1244-1247.

Maurya, V.P., Naqvi, S.M.K. and Mittal, J.P. 2004. Effect of dietary energy level on physiological responses and reproductive performance in Malpura sheep in hot semi-arid region of India. Small Rum. Res., 55: 117-122.

Regan, W.M. and Richardson, G.A. 1938. Reactions of dairy cows to changes in environmental temperatures. J. Dairy Sci., 21: 73-79.

Sharma, S., Ramesh, K., Hyder, I., Uniyal, S., Yadav, V.P., Panda, R.P., Maurya, V.P., Singh, G., Kumar, P., Mitra, A. and Sarkar. M. 2013. Effect of melatonin administration on thyroid hormones, cortisol and expression profile of heat shock proteins in goats (Capra hircus) exposed to heat stress. Small Rum. Res., 112(1): 216-223.

Sinkalu, O.V. Ayo, J.O. Abimbola, A.A. and Ibrahim J.E. 2014. Effects of melatonin on cloacal temperature and erythrocyte osmotic fragility in layer hens during the hot dry season. $J$. Appl. Anim. Res., 43: 52-60.

SPSS, Inc. 1997. SPSS (Statistical Package for Social Sciences) for Windows $\subset 1993$ Version 160 SPSS Inc., Chicago, IL.

Srikandakumar, A., Johnson, E.H. and Mahgoub, O. 2003. Effect of heat stress on respiratory rate, rectal temperature and blood chemistry in Omani and Australian Merino sheep. Small Rum. Res., 49: 193-198.

Vaidya, M.M., Kumar, P. and Singh, S.V. 2011. Circadian changes in heat storage and heat loss through sweating and panting in Karan Fries cattle during different seasons. Biol. Rhythm Res., 43: 137-146.

Wankar, A.K., Singh, G. and Yadav, B. 2014. Thermoregulatory and adaptive responses of adult buffaloes (Bubalus bubalis) during hyperthermia: Physiological, behavioral and metabolic approach. Vet. World, 10: 825-830. 